\title{
PELANGGARAN WISATAWAN TERHADAP PERATURAN PENGUNJUNG DI CANDI BOROBUDUR
}

\author{
Aan Wahyuni Lestari \\ Program Studi Arsitektur Universitas Gadjah Mada \\ Email: aan.wahyuni.l@gmail.com \\ Diananta Pramitasari \\ Program Studi Arsitektur Universitas Gadjah Mada \\ Email: dpramitasari@ugm.ac.id \\ Ahmad Saifullah MJ \\ Program Studi Arsitektur Universitas Gadjah Mada \\ Email: saiful_tgp@yahoo.co.id
}

\begin{abstract}
Visitor Code of Conduct is an effort to minimize negative impact caused by tourist visitation to the Borobudur Temple. It have been applied since 2010 and socialized to the tourists by regulatory boards, security officers and guides. However, there are still tourist violations towards it. This research aims to describe the characteristics of tourist violation towards Visitor Code of Conduct and to find out the causative factors of the tourist violation towards Visitor Code of Conduct. The data was collected by observation, interview and questionnaire, and analysed by descriptive analysis. The results of the research are: 1) the most violator towards Visitor Code of Conduct are male, 17-24 years old, well educated, from outside Java, repeater, visiting for recreation, with friends or family, with most violations is related to stupas (73.8\%) 2) factor of motive, knowledge of the Visitor Code of Conduct, knowledge of the violation's impact and enforcement of regulation has caused tourists to commit violation, while attitudes toward Visitor Code of Conduct and environment cues do not cause tourists violation.
\end{abstract}

Keywords: violation, tourist, Visitor Code of Conduct, Borobudur Temple 


\section{Pendahuluan}

Cagar budaya merupakan warisan budaya yang bersifat kebendaan baik berupa benda cagar budaya, bangunan cagar budaya, struktur cagar budaya, situs cagar budaya dan kawasan cagar budaya yang perlu dilestarikan keberadaannya karena memiliki nilai penting bagi sejarah, ilmu pengetahuan, pendidikan, agama dan/atau kebudayaan melalui proses penetapan (UU No. 11/2010). Seperti yang tercantum dalam UU No. 11 Tahun 2010, cagar budaya dapat dimanfaatkan untuk kepentingan agama, sosial budaya, pendidikan, ilmu pengetahuan dan pariwisata. Walaupun demikian, pemanfaatan cagar budaya tetap harus memperhatikan kelestarian cagar budaya itu sendiri.

Salah satu objek wisata cagar budaya di Indonesia adalah Candi Borobudur. Candi Borobudur merupakan Candi Buddha terbesar di Indonesia dan terletak di Kecamatan Borobudur, Kabupaten Magelang, Jawa Tengah. Pada tahun 1991, UNESCO menetapkan Candi Borobudur sebagai Warisan Budaya Dunia Nomor 592. Candi Borobudur dikelola oleh Balai Konservasi Borobudur pada zona 1 dan PT. Taman Wisata Candi Borobudur pada zona 2. Keberadaan dua pengelola ini menyebabkan kontradiksi dalam pengelolaan Candi Borobudur. Balai Konservasi Borobudur bertugas untuk melaksanakan konservasi dan pelestarian Candi Borobudur dan Kawasan Cagar Budaya Borobudur, sedangkan PT. Taman Wisata Candi Borobudur bertujuan menciptakan keuntungan ekonomis dalam mengusahakan lingkungan Candi Borobudur sebagai sebuah taman wisata yang bersifat budaya, pendidikan dan rekreasi dengan cara mendatangkan wisatawan sebanyak-banyaknya ke Candi Borobudur.

Dalam kurun waktu 2012-2016, rata-rata peningkatan jumlah wisatawan mencapai 6,61 \% dengan jumlah wisatawan yang berkunjung ke Candi Borobudur pada tahun 2016 mencapai 3.892.916 orang. Kehadiran wisatawan ini di satu sisi dapat meningkatkan devisa negara dan pendapatan masyarakat sekitar namun disisi lain dapat berdampak negatif terhadap struktur candi. Taufik (2005) mengemukakan dua faktor utama penyebab 
terjadinya kerusakan pada struktur candi, yaitu faktor dari dalam (biasanya disebabkan oleh keroposnya bangunan itu sendiri) dan faktor dari luar (dikarenakan oleh alam biotik dan abiotik serta aktivitas manusia baik yang disengaja maupun tidak disengaja). Beberapa jenis kerusakan yang disebabkan oleh manusia akibat pemanfaatan struktur Candi Borobudur untuk kegiatan pariwisata antara lain : 1) keausan yang terjadi pada lantai, tangga candi maupun pinggiran stupa teras akibat gesekan antara batu penyusun candi dengan butiran pasir yang dibawa wisatawan melalui alas kaki, 2) vandalisme berupa coretan batu dan patahnya bagian relief akibat dipegang wisatawan, dan 3) pergeseran batu penyusun candi (hasil wawancara salah seorang arkeolog di Balai Konservasi Borobudur pada tanggal 28 Januari 2016).

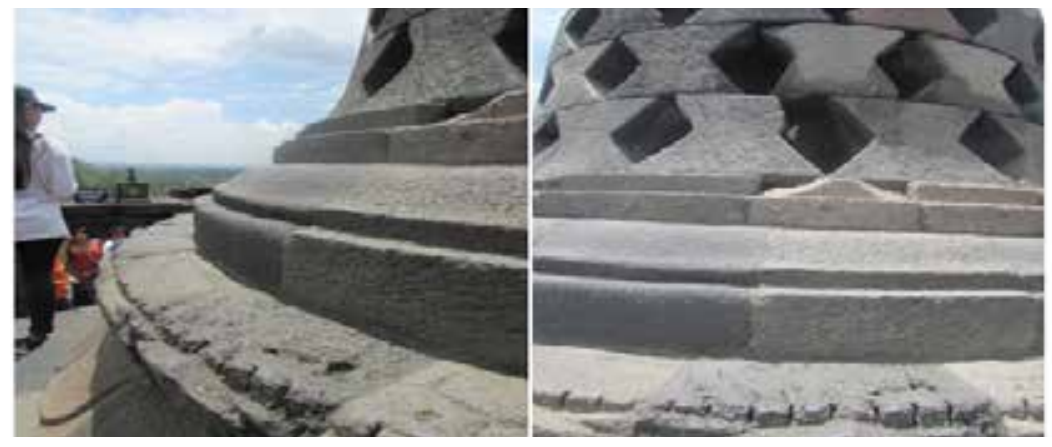

Gambar 1

Keausan pada Relief Dekoratis Stupa Teras yang Berisikan Arca Kunto Bimo

Sumber : Dok. Pribadi 2016

Dalam penelitian Taufik (2005), menemukan bahwa pengunjung merupakan pihak yang paling bertanggung jawab atas kerusakan yang terjadi di Candi Borobudur. Walaupun demikian, kedatangan wisatawan ke Candi Borobudur yang cenderung meningkat setiap tahun tidak mungkin ditolak. Oleh karena itu, perlu diperhatikan bagaimana agar keberadaan wisatawan tidak mempercepat kerusakan. Salah satu upaya yang dilakukan untuk mengurangi dampak negatif wisatawan adalah dengan diberlakukannya Peraturan Pengunjung. Peraturan Pengunjung 
mulai diberlakukan sejak tahun 2010 dan telah disosialisasikan kepada wisatawan melalui papan peraturan, petugas keamanan, guide dan fotografer. Namun, masih terjadi pelanggaran yang dilakukan wisatawan terhadap Peraturan Pengunjung. Pelanggaran akan semakin meningkat seiring dengan meningkatnya jumlah wisatawan yang berkunjung ke Candi Borobudur terutama saat weekend maupun peak season.

Candi Borobudur telah ditetapkan sebagai salah satu destinasi prioritas oleh Kementerian Pariwisata dan ditargetkan akan dikunjungi oleh 7 juta wisatawan pada tahun 2019. Dengan semakin meningkatnya jumlah wisatawan yang berkunjung, potensi pelanggaran yang mungkin terjadi akan semakin besar pula. Pelanggaran yang dilakukan oleh wisatawan terhadap peraturan yang berlaku menyebabkan kerusakan terhadap sumber daya sehingga memerlukan biaya yang besar untuk memperbaiki kerusakan tersebut, tidak termasuk kerusakan sumber daya yang tidak dapat diperbaiki (Johnson dan Van de Kamp 1994 dalam Ward dan Roggenbuck 2003). Penelitian ini bertujuan untuk mendapatkan gambaran karakteristik pelanggaran wisatawan terhadap Peraturan Pengunjung di Candi Borobudur dan mengetahui faktor-faktor yang menyebabkan wisatawan melanggar Peraturan Pengunjung di Candi Borobudur.

\section{Teori dan Metode Penelitian}

Dalam penelitian ini, penulis menggunakan beberapa teori yang relevan antara lain tinjauan tentang heritage tourism, tinjauan tentang Peraturan Pengunjung, tinjauan tentang wisatawan dan tinjauan tentang pelanggaran wisatawan dan faktor-faktor yang menyebabkan wisatawan melanggar Peraturan Pengunjung. Beberapa penelitian mengenai pelanggaran atau ketidakpatuhan yang diasosiasikan dengan perlindungan sumber daya alam dapat digunakan untuk memahami pelanggaran yang dilakukan di sumber daya budaya dikarenakan kesamaan masalah yang dihadapi. 


\section{Tabel 1}

Kerangka Teori

\begin{tabular}{|c|c|c|c|c|}
\hline No & Kajian & Teori & Penjabaran & $\begin{array}{c}\text { Pertanyaan Pene- } \\
\text { litian }\end{array}$ \\
\hline \multirow[t]{3}{*}{1.} & \multirow[t]{3}{*}{$\begin{array}{l}\text { Karak- } \\
\text { teristik } \\
\text { Pelang- } \\
\text { garan }\end{array}$} & \multirow{3}{*}{$\begin{array}{c}\text { Perilaku } \\
\text { (Ajzen dan Fishbein 1995) } \\
\text { Pelanggaran } \\
\text { (Young 1979) } \\
\text { Heritage Tourism } \\
\text { (Timothy dan Boyd 2003) } \\
\text { Kearsitekturan Candi Boro- } \\
\text { budur } \\
\text { (Sutopo dkk. 2013) }\end{array}$} & $\begin{array}{l}\text { Jenis Pelang- } \\
\text { garan }\end{array}$ & \multirow[t]{3}{*}{$\begin{array}{l}\text { Bagaimana kara- } \\
\text { kteristik pelang- } \\
\text { garan wisatawan } \\
\text { terhadap Per- } \\
\text { aturan pengun- } \\
\text { jung di Candi } \\
\text { Borobudur? }\end{array}$} \\
\hline & & & $\begin{array}{l}\text { Objek } \\
\text { Pelanggaran }\end{array}$ & \\
\hline & & & $\begin{array}{l}\text { Karakter- } \\
\text { istik wisa- } \\
\text { tawan yang } \\
\text { melanggar }\end{array}$ & \\
\hline \multirow[t]{6}{*}{2.} & \multirow{6}{*}{$\begin{array}{l}\text { Faktor } \\
\text { penyebab } \\
\text { pelang- } \\
\text { garan }\end{array}$} & \multirow[t]{2}{*}{$\begin{array}{c}\text { Pelanggaran normatif } \\
\text { (Gramann dan Vander Stoep } \\
\text { 1987) }\end{array}$} & Motif & \multirow{6}{*}{$\begin{array}{l}\text { Faktor-faktor apa } \\
\text { saja yang me- } \\
\text { nyebabkan wisa- } \\
\text { tawan melanggar } \\
\text { Peraturan Pen- } \\
\text { gunjung di Candi } \\
\text { Borobudur? }\end{array}$} \\
\hline & & & $\begin{array}{l}\text { Penge- } \\
\text { tahuan } \\
\text { terhadap } \\
\text { peraturan }\end{array}$ & \\
\hline & & $\begin{array}{c}\text { Pelanggaran } \\
\text { (Kagan dan Scholz 1984) } \\
\text { Ketidak patuhan } \\
\text { (Anderson dan Smith 2014) }\end{array}$ & $\begin{array}{l}\text { Pengeta- } \\
\text { huan terha- } \\
\text { dap dampak } \\
\text { pelanggaran }\end{array}$ & \\
\hline & & \multirow{3}{*}{$\begin{array}{c}\text { Penegakan peraturan } \\
\text { (Soekanto 2003) } \\
\text { Kepatuhan } \\
\text { (Becker 1968) } \\
\text { Code of Conduct } \\
\text { (Mason \& Mowforth 1995) }\end{array}$} & $\begin{array}{l}\text { Sikap ter- } \\
\text { hadap per- } \\
\text { aturan }\end{array}$ & \\
\hline & & & $\begin{array}{l}\text { Isyarat ling- } \\
\text { kungan }\end{array}$ & \\
\hline & & & $\begin{array}{l}\text { Penegakan } \\
\text { peraturan }\end{array}$ & \\
\hline
\end{tabular}


Penelitian ini merupakan penelitian deskriptif. Penelitian ini dimulai dengan pengumpulan data baik data primer dan data sekunder. Data primer dikumpulkan melalui kuesioner, wawancara dan observasi sedangkan data sekunder dikumpulkan melalui dokumentasi dan tinjauan literatur. Kuesioner disebarkan dengan metode purposive sampling dengan kriteria responden wisatawan nusantara yang berkunjung bukan untuk ziarah, penelitian, bekerja maupun melakukan foto pre wedding di Candi Borobudur, berperilaku tidak sesuai dengan salah satu atau lebih peraturan pengunjung baik berdasarkan pengamatan langsung maupun konfirmasi dari wisatawan, berusia minimal 17 tahun dan maksimal 65 tahun.

Data yang telah diperoleh kemudian dianalisa berdasarkan tujuan penelitian. Untuk mendapatkan gambaran karakteristik pelanggaran wisatawan terhadap Peraturan Pengunjung dilakukan dengan melakukan analisis distribusi frekuensi pada hasil self-report wisatawan mengenai jenis pelanggaran dan karakteristik wisatawan yang melanggar, kemudian dilakukan tabulasi silang antara jenis pelanggaran dan karakteristik wisatawan yang melanggar sehingga diketahui jenis pelanggaran yang dilakukan berdasarkan karakteristik wisatawan yang melanggar. Selanjutnya bersama-sama hasil wawancara dan observasi dianalisis secara deskriptif. Hasil observasi dan wawancara mengenai objek pelanggaran dianalisis secara deskriptif dengan mengaitkan dengan jenis pelanggaran yang terjadi di objek tersebut. Sedangkan untuk mengetahui faktorfaktor yang menyebabkan wisatawan melakukan pelanggaran terhadap Peraturan Pengunjung, hasil self-report wisatawan mengenai faktor-faktor penyebab pelanggaran, antara lain motif, pengetahuan terhadap peraturan, pengetahuan terhadap dampak pelanggaran, sikap terhadap peraturan, isyarat lingkungan dan penegakan peraturan dianalisis menggunakan distribusi frekuensi, kemudian masing-masing faktor penyebab pelanggaran ditabulasi silang dengan jenis pelanggaran dan karakteristik 
wisatawan yang melanggar sehingga diketahui faktorfaktor penyebab pelanggaran berdasarkan pelanggaran yang dilakukan dan faktor-faktor penyebab pelanggaran berdasarkan karakteristik wisatawan yang melanggar. Selanjutnya dianalisis secara deskriptif dengan menghubungkan dengan data-data lain yang diperoleh berdasarkan wawancara.

Setelah data dianalisa, kemudian dibahas dengan mendialogkan dengan teori-teori terkait sehingga dapat diketahui bagaimana karakteristik pelanggaran wisatawan terhadap peraturan pengunjung dan faktor-faktor yang menyebabkan terjadinya pelanggaran. Selanjutnya dirumuskan kesimpulan berupa gambaran karakteristik pelanggaran terhadap peraturan pengunjung dan faktor-faktor yang menyebabkan, serta disusun rekomendasi penelitian berupa tindakan-tindakan preventif yang dapat dilakukan berdasarkan hasil penelitian.

Dalam penelitian ini, pelanggaran peraturan dibatasi pada pelanggaran peraturan yang berdampak langsung terhadap struktur candi antara lain larangan untuk : 1) duduk atau berdiri di stupa dan pagar langkan, 2) memasukkan tangan pada stupa candi, 3) memanjat, 4) mencoret-coret, dan 5) memindahkan susunan batu. Identifikasi karakteristik pelanggaran dibatasi pada aspek jenis pelanggaran, objek pelanggaran dan karakteristik wisatawan yang melanggar. Aspek karakteristik pelanggaran berupa jenis pelanggaran dan karakteristik wisatawan yang melanggar, sumber informasi dibatasi pada hasil self-report wisatawan. Sedangkan aspek objek pelanggaran, sumber informasi dibatasi berdasar hasil observasi terhadap kecenderungan terjadinya pelanggaran secara visual dan hasil wawancara. Faktor-faktor yang menyebabkan terjadinya perilaku melanggar amat bervariasi, namun penelitian ini membatasi diri pada motif, pengetahuan terhadap peraturan, pengetahuan terhadap dampak pelanggaran, sikap terhadap peraturan, isyarat lingkungan, dan penegakan peraturan dengan sumber informasi dibatasi pada hasil self-report wisatawan. 


\section{Pembahasan}

Karakteristik Pelanggaran Wisatawan Terhadap Peraturan Pengunjung

Suatu pelanggaran dideskripsikan dengan mengetahui siapa melakukan apa, kapan dan dimana, serta mengetahui mengapa suatu pelanggaran terjadi untuk menjelaskan suatu pelanggaran (Ajzen dan Fishbein 2005 dalam Arias 2015). Karakteristik pelanggaran wisatawan terhadap Peraturan Pengunjung meliputi jenis pelanggaran, objek pelanggaran dan karakteristik wisatawan yang melanggar. Pelanggaran terjadi ketika perilaku aktual yang ditunjukan oleh wisatawan berseberangan dengan perilaku yang diharapkan berdasarkan peraturan pengunjung yang berlaku (Oran Young 1979 dalam Simmons 1998). Pelanggaran yang paling banyak dilakukan adalah memanjat stupa $(19,1 \%)$, sedangkan pelanggaran yang paling sedikit terjadi adalah menaiki singa (3,8\%).

\section{Tabel 2}

Jenis Pelanggaran Wisatawan Terhadap Peraturan Pengunjung

\begin{tabular}{|c|l|l|c|c|}
\hline No & Peraturan Pengunjung & \multicolumn{1}{|c|}{ Jenis Pelanggaran } & Frek & $\%$ \\
\hline \multirow{2}{*}{1} & \multirow{2}{*}{$\begin{array}{l}\text { Dilarang duduk dan } \\
\text { berdiri di stupa dan } \\
\text { pagar langkan }\end{array}$} & Duduk di stupa & 33 & 11,3 \\
\cline { 3 - 5 } & & Duduk di pagar langkan & 24 & 8,2 \\
\cline { 3 - 5 } & $\begin{array}{l}\text { Memasukkan tangan } \\
\text { dalam stupa }\end{array}$ & $\begin{array}{l}\text { Berdiri di stupa } \\
\text { Merdiri di pagar langkan }\end{array}$ & 21 & 7,2 \\
\hline \multirow{2}{*}{2} & $\begin{array}{l}\text { Memegang patung } \\
\text { Buddha dalam stupa }\end{array}$ & 24 & 7,8 \\
\cline { 3 - 6 } & & $\begin{array}{l}\text { Memegang patung } \\
\text { Buddha di stupa terbuka }\end{array}$ & 54 & 18,4 \\
\hline \multirow{2}{*}{3} & \multirow{2}{*}{ Dilarang memanjat } & Memanjat stupa & 56 & 19,1 \\
\cline { 3 - 6 } & & Memanjat pagar langkan & 19 & 6,5 \\
\cline { 3 - 6 } & & Menaiki singa & 11 & 3,8 \\
\hline
\end{tabular}

Sumber : diolah dari data primer, 2017

Wisata heritage merupakan wisata experiental dalam arti mencari pengalaman atau merasakan bagian dari sejarah sebuah 
tempat (Hall dan Zeppel 1990 dalam Timothy dan Boyd 2003). Wisatawan mengartikan pengalaman tersebut tidak hanya dengan melihat, tetapi juga dengan duduk, berdiri, memegang bahkan memanjat struktur candi. Banyak wisatawan yang menyadari pengalaman sebagai nilai tambah dari kunjungan mereka tersebut. Selain itu, wisatawan mencari pengalaman yang otentik dari heritage yang membedakan heritage yang dikunjungi dengan heritage lainnya (Yankholmes dan Akyemampong 2010). Sebesar 73,8\% pelanggaran terhadap Peraturan Pengunjung berkaitan dengan stupa. Stupa dilihat sebagai pembeda Candi Borobudur dibandingkan candi lainnya seperti Candi Prambanan, Candi Mendut maupun Angkor Wat. Walaupun demikian, pelanggaran hanya berkaitan dengan stupa induk dan stupa teras yang terletak di bagian Arupadhatu. Hal ini dikarenakan masih terkonsentrasinya wisatawan nusantara saat berkunjung ke Candi Borobudur di bagian ini. Bagi sebagian besar wisatawan, point of interest dari Candi Borobudur hanya terletak pada bagian ini. Selain itu, Candi Borobudur bukanlah satu-satunya destinasi yang dikunjungi pada hari itu sehingga wisatawan pada umumnya mempunyai waktu yang terbatas untuk menikmati Candi Borobudur.

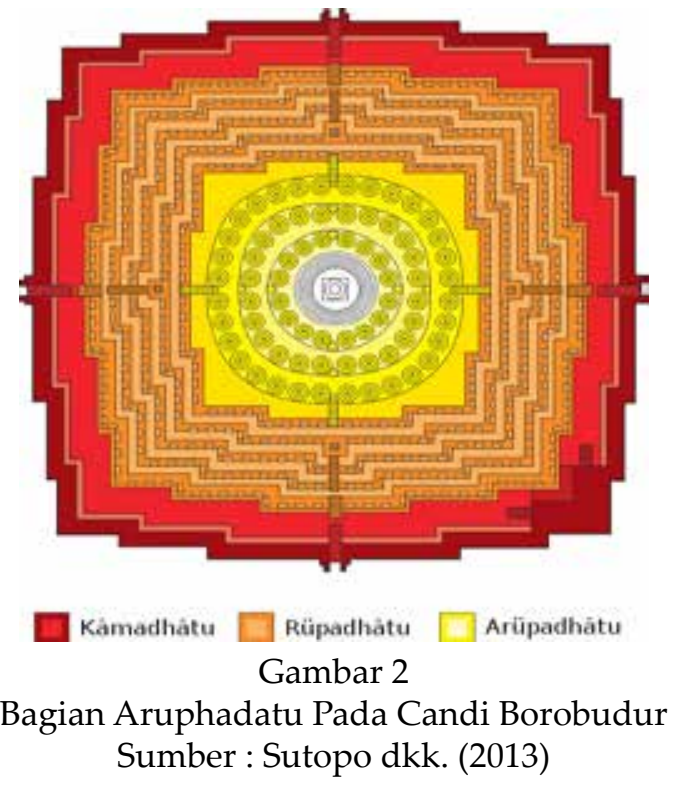


Selain stupa, objek lain yang menjadi pelanggaran adalah pagar langkan dengan jenis pelanggaran berupa duduk, berdiri serta memanjat pagar langkan (22,5\%), terutama pada pagar langkan yang sudah tidak utuh baik yang tidak mempunyai kepala langkan maupun yang hanya tersisa kaki langkan. Hal ini berkaitan penempatan papan peraturan yang tidak sesuai dengan pelanggaran yang dilakukan. Dalam penelitian Hayes (2008), menemukan lokasi papan peraturan mempengaruhi proses penerimaan informasi oleh wisatawan sehingga Peraturan Pengunjung akan lebih efektif jika ditempatkan sesuai dengan pelanggaran yang dilakukan atau yang menurut wisatawan sesuai dengan yang mereka lakukan. Di Candi Borobudur sendiri penempatan informasi mengenai dilarang memanjat pada pagar langkan yang hanya tersisa kaki langkan menjadi tidak tepat karena pelanggaran yang dilakukan adalah duduk atau berdiri di pagar langkan. Hal ini menyebabkan wisatawan tetap melakukan pelanggaran dikarenakan informasi pada papan peraturan yang berbeda dengan apa yang mereka lakukan. Selain berkaitan dengan

Objek lain yang menjadi pelanggaran adalah singa dengan pelanggaran berupa menaiki singa (3,8\%). Pada saat naik, singa yang cenderung untuk dinaiki adalah singa pada bagian kiri dan kanan tangga masuk pada selasar di sisi timur atau selatan struktur candi. Sedangkan pada saat turun candi, singa yang cenderung dinaiki adalah singa yang berada pada plateu disi sisi barat atau utara. Hal ini dikarenakan alur kunjungan wisatawan yang cenderung naik ke candi dari sisi timur dan selatan dan turun candi melalui sisi barat dan utara candi. Pelanggaran menaiki singa oleh Balai Konservasi Borobudur dikategorikan sebagai pelanggaran memanjat.

Wisatawan merupakan target dari sejumlah peraturan yang berlaku. Manajemen intervensi dapat difokuskan ketika diketahui siapa yang melakukan pelanggaran terhadap peraturan yang berlaku (Arias 2015). Adapun karakteristik wisatawan yang melanggar Peraturan Pengunjung dibedakan berdasarkan asal 
wisatawan, usia, jenis kelamin, pendidikan, frekuensi kunjungan, teman perjalanan dan maksud kunjungan (Timothy dan Boyd 2003 dan Smith 1989). Secara umum, karakteristik wisatawan yang melanggar menggambarkan karakteristik wisatawan yang berkunjung ke situs heritage, antara lain remaja (17-24 tahun), berpendidikan tinggi, berasal dari luar daerah, berkunjung bersama grup baik keluarga maupun teman dan bertujuan untuk rekreasi. Walaupun demikian, jumlah wisatawan laki-laki yang melanggar, sedikit lebih banyak dibandingkan wisatawan perempuan dengan selisih sebesar 2\%. Hooper-Greenhill (1988 dalam Timothy dan Boyd 2003) mengatakan pada umumnya wisatawan yang berkunjung ke situs heritage lebih banyak perempuan daripada laki-laki, namun seperti dalam penelitian Harahap (2016), laki-laki lebih tidak patuh daripada perempuan. Hampir semua jenis pelanggaran yang terjadi, lebih banyak dilakukan oleh laki-laki dibandingkan perempuan, kecuali jenis pelanggaran berupa berdiri di stupa, memegang patung Buddha dalam stupa dan menaiki singa yang lebih banyak dilakukan oleh perempuan.

Selain itu, pelanggaran justru lebih banyak dilakukan oleh repeater. Dalam penelitian Hayes (2008), menemukan bahwa pengalaman wisatawan pada kunjungan sebelumnya di situs tersebut atau pengalaman wisatawan pada kunjungan ke situs lain yang sejenis menyebabkan wisatawan menjustifikasi pelanggaran yang dilakukan berdasarkan pengalaman masa lalu. Wisatawan menjustifikasi pelanggaran yang dilakukan dengan mengatakan tidak ada larangan pada kunjungan sebelumnya. Hal ini dimungkinkan pada saat wisatawan berkunjung terakhir kali ke Candi Borobudur, belum diberlakukan Peraturan Pengunjung atau sudah diberlakukan, namun wisatawan tidak memperhatikan peraturan yang disampaikan baik melalui papan peraturan, petugas keamanan maupun guide. Hampir semua wisatawan melakukan semua jenis pelanggaran yang terjadi, namun, wisatawan yang berasal dari masyarakat sekitar, DKI, Jabar, Banten atau Jatim, berusia 56-65 tahun, berpendidikan SMP 
atau Pascasarjana dan berkunjung ke Candi Borobudur sendiri atau bersama pasangan, hanya terbatas melakukan pelanggaranpelanggaran tertentu.

\section{Faktor-Faktor Yang Menyebabkan Wisatawan Melanggar Peraturan Pengunjung}

Secara keseluruhan pelanggaran diawali oleh faktor-faktor yang melatarbelakangi baik faktor personal (motif, pengetahuan terhadap peraturan, pengetahuan terhadap dampak pelanggaran dan sikap terhadap peraturan) maupun faktor situasional (isyarat lingkungan dan penegakan peraturan). Pelanggaran merupakan produk dari tujuan atau kebutuhan (Knopf dan Dustin 1992 dalam Ward dan Roggenbuck 2003). Kebutuhan itu sendiri memiliki kaitan erat dengan motif. Sebagian besar pelanggaran yang terjadi berkaitan dengan foto $(39,8 \%)$, baik untuk berfoto $(36,8 \%)$ maupun cek foto $(3 \%)$.

Berfoto tampaknya telah menjadi sesuatu yang penting bahkan bisa dikatakan jika wisatawan berkunjung ke suatu destinasi untuk berfoto. Semua jenis pelanggaran yang terjadi dilatarbelakangi untuk berfoto. Wisatawan mengambil banyak foto pada saat liburan dan menilai berfoto merupakan pengalaman yang penting dilakukan dan berdampak pada emosi positif wisatawan dan kepuasan yang lebih tinggi. Sebagian besar wisatawan yang melakukan pelanggaran untuk berfoto adalah wisatawan remaja (17-24 tahun). Salah satu foto yang paling sering diambil adalah foto selfie. Melalui selfie (berfoto sendiri), wisatawan mengembangkan dan menggunakan potensi diri mereka dengan menampilkan yang terbaik dari mereka untuk kemudian ditunjukkan ke orang lain terutama melalui media sosial sehingga kesan yang dimiliki orang lain terhadap dirinya dapat bernilai positif. Hal ini berkaitan dengan kebutuhan akan aktualisasi diri (Rakhmat 2003).

Selain berfoto, yang melatarbelakangi wisatawan melakukan pelanggaran terhadap Peraturan Pengunjung antara lain melihat pemandangan sekitar $(14,2 \%)$, rasa ingin tahu akan 
Candi Borobudur (13,2\%), melihat kelompok referensi melanggar baik teman, keluarga, orangtua, guru atau pasangan $(10,3 \%)$, beristirahat melepas lelah $(9,1 \%)$, adanya mitos Kunto Bimo $(9,1 \%)$ dan disuruh oleh kelompok referensi untuk melakukan pelanggaran $(4,3 \%)$.

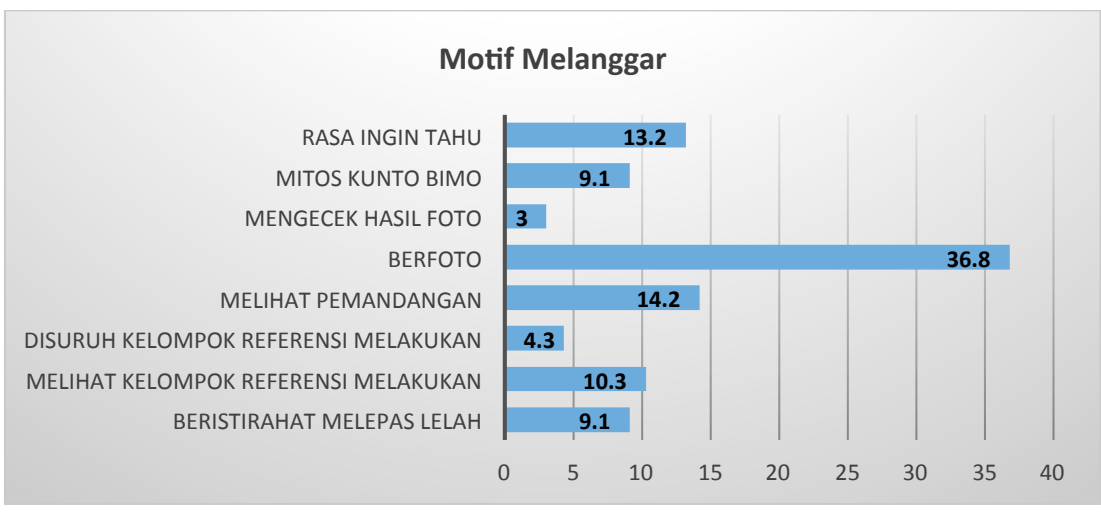

\section{Gambar 3}

Motif Wisatawan Melakukan Pelanggaran

Sumber : Diolah dari data primer 2017

Wisatawan melakukan pelanggaran terhadap Peraturan Pengunjung dalam rangka mencapai tujuan tertentu. Wisatawan merasa mereka memiliki hak untuk melihat dan mendapatkan pengalaman selama berkunjung ke Candi Borobudur, sehingga eksistensi dari konservasi heritage tergantung pada apa yang mereka rasakan tentang heritage tersebut (Knudson, dkk. 1995 dalam Timothy dan Boyd 2003). Dalam penelitian Ratnadewi (2005) ditemukan bahwa candi masih dilihat sebagai objek apa adanya dan pengelolaan atau manajemen atraksi belum mampu mempromosikan unsur sejarah. Wisatawan lebih banyak memandang Candi Borobudur sebagai objek yang menarik untuk difoto dibandingkan Candi Borobudur sebagai Warisan Budaya Dunia bahkan masih ada wisatawan yang memandang Candi Borobudur hanya sebagai batu.

Menurut Gramann dan Vander Stoep (1987), pelanggaran terjadi karena pengunjung tidak menyadari atau tidak mengetahui 
dengan perilaku yang diharapkan di suatu area sehingga mereka percaya mereka tidak melakukan pelanggaran. Sebagian besar wisatawan mengetahui diberlakukannya Peraturan Pengunjung (77\%) sedangkan 23\% lainnya tidak tahu diberlakukannya Peraturan Pengunjung. Hal-hal yang menyebabkan wisatawan tidak tahu diberlakukannya Peraturan Pengunjung antara lain tidak memperhatikan peraturan pengunjung yang ada dengan jelas $(52,2 \%)$, tidak melihat papan peraturan $(26,1 \%)$ atau tidak memperhatikan peraturan yang disampaikan oleh petugas keamanan (21,7\%). Wisatawan yang menjawab tidak tahu adanya Peraturan Pengunjung sebagian besar adalah laki-laki, berusia 17-24 tahun, berpendidikan setingkat SLTA, berkunjung bersama teman, first timer dan berkunjung ke candi untuk tujuan rekreasi. Walaupun demikian, semua jenis pelanggaran yang terjadi dilakukan oleh wisatawan, baik yang tahu adanya Peraturan Pengunjung maupun tidak.

Sebesar $77 \%$ wisatawan mengetahui diberlakukannya Peraturan Pengunjung, namun sebagian besar wisatawan justru tidak mengetahui jika apa yang mereka lakukan juga merupakan pelanggaran terhadap Peraturan Pengunjung. Peraturan mengenai larangan memasukkan tangan ke dalam stupa merupakan peraturan yang paling banyak dilanggar (36,2\%). Namun peraturan ini hanya diketahui $9,2 \%$ yang melanggar dengan memasukkan tangan ke dalam stupa, 4,3\% memegang arca dalam stupa dan 6,3\% memegang arca di stupa terbuka sehingga keterbatasan pengetahuan terhadap isi peraturan menyebabkan wisatawan masih melanggar Peraturan Pengunjung walaupun mengetahui adanya Peraturan Pengunjung di Candi Borobudur. Dalam penelitian Suroso (2000 dalam Sulesuryana 2007), menemukan bahwa isi dari peraturan lalu lintas hanya sebagian kecil yang diketahui, bahkan sekitar 30\% lainnya tidak tahu sama sekali isi dari peraturan lalu lintas sehingga mendorong tingginya perilaku melanggar pada usia remaja di perkotaan.

Pelanggaran juga terjadi ketika wisatawan tidak mengetahui konsekuensi dari pelanggaran tersebut terhadap kerusakan 
sumber daya (Gramann dan Vander Stoep 1987). Secara umum, sebagian besar wisatawan mengetahui dampak pelanggaran terhadap candi (75\%), sedangkan 25\% lainnya tidak mengetahui jika dampak pelanggaran. Sebagian besar wisatawan yang menjawab tidak tahu dampak pelanggaran adalah wisatawan berjenis kelamin laki-laki, first timer, berasal dari luar daerah. Walaupun mengetahui dampak pelanggaran secara umum, namun wisatawan justru tidak tahu jika apa yang mereka lakukan juga dapat merusak struktur candi sehingga pelanggaran masih terjadi. Memanjat stupa merupakan pelanggaran yang paling banyak terjadi $(19,1 \%)$. Namun, dampak yang berkaitan dengan pelanggaran ini hanya diketahui oleh 14,8\% mengenai dampak gesekan alas kaki dan batu candi yang menimbulkan keausan $17 \%$ mengenai dampak keausan pada relief dekoratis dan $7 \%$ mengenai dampak keringat manusia yang mempercepat proses pelapukan. Hal ini menunjukkan sebagian besar wisatawan tidak mengetahui dampak pelanggaran yang berkaitan dengan pelanggaran yang mereka lakukan. Secara umum, dampak yang paling sedikit diketahui adalah dampak keringat manusia yang mempercepat proses pelapukan pada batu candi $(8,7 \%)$. Dampak ini berkaitan dengan segala kegiatan menyentuh bagian candi sehingga dapat dikatakan hampir semua pelanggaran yang dilakukan berkaitan dengan dampak ini kecuali beberapa pelanggaran antara lain berdiri di bagian dasar stupa teras, berdiri di kaki pagar langkan, duduk di stupa tanpa tangan menyentuh stupa atau duduk di kaki pagar langkan.

Kurangnya pengetahuan terhadap isi peraturan maupun dampak pelanggaran berkaitan dengan terbatasnya sosialisasi yang dilakukan oleh pengelola pada masyarakat sekitar maupun komunitas tertentu. Sosialisasi Peraturan Pengunjung kepada wisatawan hanya terbatas pada saat wisatawan sudah berkunjung ke Candi Borobudur, bahkan belum ada sosialisasi dampak pelanggaran terhadap kerusakan candi kepada wisatawan. Sosialisasi Peraturan Pengunjung kepada wisatawan terbatas melalui papan peraturan, petugas keamanan, guide maupun fotografer, bahkan dampak pelanggaran hanya akan diketahui jika 
wisatawan bertanya kepada petugas keamanan atau guide. Hanya 13\% masyarakat sekitar yang tidak tahu Peraturan Pengunjung, sedangkan $87 \%$ lainnya berasal dari luar daerah, bahkan semua wisatawan yang tidak tahu dampak pelanggaran berasal dari luar daerah sehingga 95\% wisatawan yang melakukan pelanggaran terhadap Peraturan Pengunjung merupakan wisatawan yang berasal dari luar daerah. Peraturan Pengunjung akan kurang efektif kecuali jika dipromosikan secara baik dan disebarluaskan secara luas (Mason \& Mowforth 1995). Menurut Rogers (1974 seperti dikutip Notoatmodjo 2003), sebelum mengadopsi perilaku baru, wisatawan harus menyadari perilaku yang diharapkan sehingga peran sosialisasi menjadi penting untuk meningkatkan efektifitas Peraturan Pengunjung.

Menurut Malloy dan Fennel (1998 dalam Cole 2006), Code of Conduct dibuat berdasarkan pada apa yang benar dan salah atau konsekuensi dari suatu tindakan. Dalam penelitian Gramann dan Bonifield (1995), menemukan subjek akan mematuhi peraturan ketika mereka diberitahu alasan adanya peraturan dan konsekuensi negatif untuk sumber daya. Peraturan Pengunjung di Candi Borobudur sebaiknya tidak hanya menyampaikan apa yang boleh dan tidak boleh dilakukan, tetapi juga menyampaikan alasan dan konsekuensi pelanggaran.

Sebagian besar wisatawan yang tidak tahu Peraturan Pengunjung maupun dampak pelanggaran merupakan wisatawan yang berkunjung untuk rekreasi. Dari wisatawan yang berkunjung untuk menambah pengetahuan, hanya $8,7 \%$ wisatawan yang tidak tahu peraturan dan $4 \%$ yang tidak tahu dampak pelanggaran. Menurut Miles (1986 dalam Timothy dan Boyd 2003), wisatawan yang berkunjung ke situs heritage untuk belajar sejarah situs akan memiliki perhatian yang ekstensif dan detail. Walaupun demikian, masih terdapat wisatawan yang berkunjung ke Candi Borobudur untuk menambah pengetahuan, namun justru tidak mengetahui Peraturan Pengunjung maupun dampak pelanggaran, sehingga tetap melakukan pelanggaran. Hal ini dimungkinkan ada faktor lain seperti pemenuhan ke- 
butuhan rasa ingin tahu terhadap arsitektur Candi Borobudur sehingga tidak memperhatikan Peraturan Pengunjung. Suasana yang ramai atau suhu yang panas juga mempengaruhi tingkat perhatian wisatawan terhadap peraturan yang disampaikan. Seperti yang diungkapkan Sarwono (1992), suhu yang panas dapat menurunkan tingkat perhatian seseorang terhadap sesuatu.

Wisatawan yang tidak tahu Peraturan Pengunjung dan dampak pelanggaran sebagian besar merupakan remaja dengan tingkat pendidikan SMA. Gramman dan Boniefeld (1995) menyarankan supaya efek pesan dampak pelanggaran untuk mematuhi peraturan tidak bisa digeneralisasikan pada semua sub grup. Peraturan Pengunjung dengan target wisatawan remaja dengan tingkat pendidikan SMA akan lebih efektif jika bahasa yang digunakan sederhana dibandingkan dengan bahasa yang ilmiah.

Wisatawan remaja cenderung berbagi pengalaman berwisata berupa foto-foto liburan dengan menggunakan media sosial baik facebook, path, instagram maupun youtube. Namun, foto-foto tersebut tidak hanya mempromosikan keindahan Candi Borobudur, tetapi juga mempromosikan pelanggaran yang dilakukan. Sehingga, media sosial dapat digunakan sebagai media edukasi termasuk didalamnya mensosialisasikan perilaku yang diharapkan saat berwisata di Candi Borobudur.

Pengunjung mungkin saja mengetahui Peraturan Pengunjung, tetapi tidak setuju dengan diberlakukannya peraturan tersebut (Kagan dan Scholz 1984 dalam Perdana 2009). Hampir semua wisatawanyang melanggar, setuju dengan diberlakukannya Peraturan Pengunjung (91\%). Hal ini dikarenakan wisatawan mengetahui bahwa Peraturan Pengunjung bertujuan untuk menjaga kelestarian candi (62,6\%). Walaupun bersikap positif terhadap Peraturan Pengunjung, wisatawan tetap melakukan pelanggaran. Pelanggaran yang dilakukan tidak hanya pada pelanggaran-pelanggaran tertentu tetapi semua jenis pelanggaran. Warner dan De fleur (1969 dalam Azwar 2013) memasukkannya sebagai postulat konsistensi tergantung, dimana hubungan sikap 
dan perilaku sangat ditentukan oleh faktor-faktor situasional tertentu, sehingga wisatawan tetap melanggar walaupun bersikap positif terhadap Peraturan Pengunjung. Wisatawan bisa saja mengabaikan apapun yang peraturan katakan tentang dampak perilaku tersebut terhadap lingkungan dalam rangka memperoleh manfaat bagi dirinya.

Sebagian besar wisatawan setuju diberlakukannya Peraturan Pengunjung adalah wisatawan remaja dan berkunjung bersama teman. Remaja memiliki keinginan kuat untuk diterima dalam kelompok teman sebaya dan orang dewasa (Agustiani 2006), namun teman sebaya ini bisa merupakan kelompok yang memberikan pengaruh negatif terhadap remaja (Agustiani 2006). Walaupun wisatawan remaja memiliki sikap positif terhadap peraturan tetapi tetap melakukan pelanggaran. Hal ini dimungkinkan dalam rangka pemenuhan kebutuhan untuk mendapatkan status atau dukungan dari kelompok referensi. Knopf dan Dustin (1992) dikutip oleh Ward dan Roggenbuck 2003) menyebutnya sebagai motif competence (kompetensi).

Wisatawan bisa saja bersikap positif terhadap Peraturan Pengunjung tetapi tetap melakukan pelanggaran dikarenakan adanya motif tertentu ataupun faktor-faktor situasional. Oleh karena itu, menurut Azwar (2013), untuk mengurangi hal tersebut dapat dilakukan dengan mengubah perilaku, mengubah lingkungan ataupun menambah pengetahuan baru.

Pelanggaran juga dapat terjadi ketika wisatawan melihat orang lain melakukan pelanggaran atau melihat jejak pelanggaran atau yang disebut releasor cues (Gramman dan Vander Stoep 1987). Penelitian terdahulu menunjukkan bahwa kondisi yang ada atau isyarat lingkungan, dapat mempengaruhi perilaku seseorang (Hayes 2008:18) sehingga kondisi lingkungan yang mempromosikan pelanggaran dapat menghambat pengunjung untuk melakukan perilaku sebaliknya. Namun, isyarat lingkungan berupa pelanggaran yang dilakukan oleh orang lain tidak menyebabkan sebagian besar wisatawan melakukan pelanggaran (86\%), bahkan beberapa wisatawan justru akan menegur 
wisatawan lain yang melanggar peraturan. Begitu pula isyarat lingkungan berupa jejak pelanggaran yaitu coret-coretan, tidak menyebabkan sebagian besar wisatawan melakukan pelanggaran yang sama (99\%).

Pelanggaran terjadi baik ketika individu melihat orang lain melakukan pelanggaran atau melihat jejak pelanggaran. (Gramann dan Vander Stoep 1987). Walaupun demikian, sebesar $86 \%$ wisatawan yang melihat pelanggaran wisatawan lain (bukan termasuk kelompok referensi), tidak menyebabkan wisatawan melakukan pelanggaran.

Wisatawan yang merasionalisasikan pelanggaran berdasarkan pelanggaran yang dilakukan wisatawan lain terlibat pada hampir semua jenis pelanggaran kecuali menaiki singa, namun bagi wisatawan lain yang melanggar Peraturan Pengunjung bukan dikarenakan melihat orang lain melakukan pelanggaran, justru terlibat pada semua jenis pelanggaran. Hal ini menunjukkan ada faktor lain yang mungkin menyebabkan mereka melakukan pelanggaran seperti pemenuhan kebutuhan. Sebagian besar wisatawan yang melanggar namun tidak disebabkan melihat orang lain melakukan pelanggaran adalah remaja dan berkunjung untuk rekreasi. Masa remaja merupakan salah satu periode dalam rentang kehidupan manusia dimanan mengalami periode transisional antara masa kanak-kanak ke dewasa sehingga semua perubahan yang terjadi dalam waktu dekat berfokus pada dirinya sendiri (Agustiani 2006).

Pelanggaran juga terjadi ketika individu melihat jejak pelanggaran sehingga ingin melakukan pelanggaran yang sama. Walaupun demikian, berdasarkan analisa, sebesar 99\% wisatawan yang melihat jejak pelanggaran wisatawan lain, tidak menyebabkan wisatawan melakukan pelanggaran yang sama. Penelitian terdahulu menunjukkan bahwa kondisi yang ada atau isyarat lingkungan, dapat mempengaruhi perilaku seseorang (Hayes 2008) sehingga kondisi lingkungan yang mempromosikan pelanggaran dapat menghambat pengunjung untuk melakukan perilaku sebaliknya. Walaupun demikian, jejak pelanggaran 
wisatawan lain berupa coret-coretan tidak menyebabkan wisatawan melakukan pelanggaran. Hal ini dikarenakan wisatawan pada umumnya mengetahui jika mencoret tersebut dilarang dan mengetahui dampak mencoret terhadap batu candi.

Wisatawan yang merasionalisasikan pelanggaran berdasarkan jejak pelanggaran yang dilakukan wisatawan lain terlibat pada hampir semua jenis pelanggaran kecuali duduk distupa, memasukkan tangan ke dalam stupa, memegang patung Buddha dalam stupa dan menaiki singa, namun bagi wisatawan lain yang melanggar Peraturan Pengunjung bukan dikarenakan jejak pelanggaran orang lain, justru terlibat pada semua jenis pelanggaran. Hal ini menunjukkan ada faktor lain yang mungkin menyebabkan mereka melakukan pelanggaran seperti pemenuhan kebutuhan. Sebagian besar wisatawan yang melanggar namun tidak disebabkan oleh jejak pelanggaran adalah repeater dan berkunjung untuk rekreasi.

Wisatawan yang merasionalisasikan pelanggaran berdasarkan pelanggaran yang dilakukan wisatawan lain, terlibat pada hampir semua jenis pelanggaran kecuali menaiki singa. Begitu pula wisatawan yang merasionalisasikan pelanggaran berdasarkan jejak pelanggaran yang dilakukan wisatawan lain terlibat pada hampir semua jenis pelanggaran kecuali duduk distupa, memasukkan tangan ke dalam stupa, memegang patung Buddha dalam stupa dan menaiki singa. Namun, bagi wisatawan lain yang melanggar Peraturan Pengunjung bukan dikarenakan isyarat lingkungan justru terlibat pada semua jenis pelanggaran. Hal ini menunjukkan ada faktor lain yang mungkin menyebabkan mereka melakukan pelanggaran seperti pemenuhan kebutuhan. Sebagian besar wisatawan yang melanggar namun tidak disebabkan melihat orang lain melakukan pelanggaran adalah remaja dan berkunjung untuk rekreasi. Sedangkan sebagian besar wisatawan yang melanggar namun tidak disebabkan oleh jejak pelanggaran adalah repeater dan berkunjung untuk rekreasi.

Pelanggaran juga terjadi ketika peraturan sulit untuk ditegakkan dan risiko dituntut secara hukum kecil (Smith dan 
Anderson 2014). Terdapat kecenderungan di dalam masyarakat untuk mengartikan peraturan dan bahkan mengidentifikasikannya dengan keberadaan petugas berseragam (Soekanto 2003). Keberadaan petugas keamanan membuat wisatawan enggan melakukan pelanggaran (55\%) bahkan $27 \%$ lainnya menyebutkan bahwa pelanggaran dilakukan jika tidak dilihat oleh petugas keamanan sehingga ketiadaan atau kurangnya petugas keamanan menyebabkan wisatawan melakukan pelanggaran. Selain keberadaan petugas berseragam, seseorang akan mematuhi peraturan jika terdapat ancaman akan adanya hukuman/sanksi yang diberikan (Becker,1968 dalam Winter dan May 2001). Sebesar 19\% wisatawan menganggap pelanggaran yang dilakukan dapat menyebabkan kerusakan terhadap Candi Borobudur sehingga perlu diberi sanksi sedangkan 12\% lainnya menganggap tidak akan melanggar Peraturan Pengunjung jika diterapkan sanksi. Walaupun demikian, menurut pengelola, teguran sudah cukup untuk membuat wisatawan tidak melakukan pelanggaran. Hal ini sesuai dengan jawaban sebagian besar wisatawan yang menyatakan teguran yang diberikan oleh petugas keamanan sudah cukup untuk membuat pengunjung tidak melakukan pelanggaran (63\%) sehingga sanksi belum diperlukan.

Keberadaan petugas keamanan berpengaruh terhadap semua jenis pelanggaran, namun penerapan sanksi belum diperlukan pada semua jenis pelanggaran. Bagi sebagian besar wisatawan yang berjenis kelamin perempuan, berasal dari Luar Jawa, berkunjung bersama teman dan first timer, keberadaan petugas keamanan mempengaruhi mereka dalam melakukan pelanggaran berupa rasa enggan melakukan pelanggaran atau akan tetap melanggar selama tidak dilihat petugas keamanan. Namun, bagi wisatawan yang sebagian besar berusia remaja, berpendidikan SMA dan berkunjung untuk rekreasi, tidak ada perbedaan anta apakah keberadaan petugas keamanan akan berpengaruh atau tidak terhadap pelanggaran. Walaupun demikian, bagi wisatawan perempuan, sanksi diperlukan dalam penegakan peraturan, sedangkan wisatawan laki-laki, 
menganggap penerapan sanksi tidak diperlukan. Sebesar $81 \%$ wisatawan yang menganggap sanksi belum diperlukan berkunjung ke Candi Borobudur untuk rekreasi. Rekreasi merupakan sebuah aktivitas yang menyenangkan sehingga dengan adanya ancaman sanksi dapat menyebabkan wisatawan merasa tidak bebas dalam berperilaku dan mengurangi kepuasan wisatawan dalam berkunjung ke Candi Borobudur. Dalam penelitian Gramann dan Bonifield (1995) menemukan jika pesan lebih efektif dibandingkan sanksi.

\section{Kesimpulan dan Rekomendasi}

Dari pemaparan pada pembahasan dapat disimpulkan :

1. Karakteristik Pelanggaran Wisatawan Terhadap Peraturan Pengunjung di Candi Borobudur

Pelanggaran yang dilakukan wisatawan terhadap Peraturan Pengunjung sebagian besar berkaitan dengan stupa (73,8\%) baik stupa induk dan stupa teras di bagian Arupadhatu. Karakteristik wisatawan yang melanggar Peraturan Pengunjung sebagian besar berjenis kelamin laki-laki, berasal dari luar daerah, berusia muda, berpendidikan tinggi, berkunjung bersama grup baik teman dan keluarga, repeater dan bertujuan untuk rekreasi. Semua jenis pelanggaran yang terjadi dilakukan oleh hampir semua wisatawan, kecuali wisatawan yang berasal dari masyarakat sekitar, Jakarta, Jawa Barat, Banten, dan Jawa Timur, berusia tua (56-65 tahun), berpendidikan SMP dan Pascasarjana dan berkunjung ke Candi Borobudur sendiri atau bersama pasangan.

2. Faktor-faktor yang menyebabkan wisatawan melanggar Peraturan Pengunjung di Candi Borobudur

Faktor-faktor yang menyebabkan wisatawan melakukan pelanggaran terdiri dari faktor personal (motif, pengetahuan terhadap dampak pelanggaran, pengetahuan terhadap peraturan) dan faktor situasional (penegakan peraturan). Faktor motif merupakan faktor utama terjadinya pelanggaran dengan motif terbesar wisatawan melakukan pelanggaran adalah motif aktualisasi diri melalui berfoto. Faktor kedua yang menyebabkan 
pelanggaran adalah pengetahuan terhadap dampak pelanggaran. Secara umum, wisatawan melakukan pelanggaran disebabkan: 1) sama sekali tidak tahu jika pelanggaran berdampak negatif terhadap struktur candi, 2) tahu jika pelanggaran berdampak negatif terhadap struktur candi, namun tidak tahu jika jenis pelanggaran yang dilakukan juga berdampak negatif pada struktur candi dan 3) tahu jika pelanggaran berdampak negatif pada struktur candi dan tahu jenis pelanggaran yang dilakukan berdampak negatif pada struktur candi namun tetap melanggar.

Faktor ketiga adalah pengetahuan terhadap Peraturan Pengunjung. Secara umum, wisatawan melakukan pelanggaran disebabkan: 1) sama sekali tidak tahu diberlakukannya Peraturan Pengunjung 2) tahu diberlakukannya Peraturan Pengunjung, namun isi peraturan yang diketahui terbatas sehingga justru tidak tahu jika perbuatan yang dilakukan juga merupakan pelanggaran terhadap Peraturan Pengunjung dan 3) tahu diberlakukannya Peraturan Pengunjung dan tahu isi peraturan namun tetap melanggar. Faktor keempat adalah penegakan peraturan berupa keterbatasan jumlah petugas keamanan dalam menegakkan peraturan sedangkan sanksi belum diperlukan dalam menegakan peraturan, karena teguran sudah cukup untuk membuat wisatawan tidak melakukan pelanggaran. Sanksi hanya diterapkan jika terjadi pelanggaran yang dilakukan secara sengaja seperti vandalisme.

Faktor sikap terhadap peraturan tidak menyebabkan wisatawan melakukan pelanggaran. Secara umum, wisatawan mempunyai sikap positif terhadap peraturan pengunjung, namun tetap melakukan pelanggaran baik dikarenakan pemenuhan kebutuhan tertentu ataupun faktor-faktor situasional. Begitu pula dengan faktor isyarat lingkungan (environtment cue) baik berupa melihat pelanggaran orang lain maupun melihat jejak pelanggaran orang lain juga tidak menyebabkan wisatawan melakukan pelanggaran.

Beberapa rekomendasi yang dapat diajukan dalam penelitian ini kepada pihak pengelola Candi Borobudur antara 
lain: 1) Peraturan Pengunjung tidak hanya berisi tentang apa yang boleh dan tidak boleh dilakukan tetapi juga alasan serta dampak negatif pelanggaran terhadap struktur candi. 2) Penempatan papan informasi seharusnya disesuaikan dengan pelanggaran yang dilakukan 3) Selain papan peraturan, perlu penambahan media informasi berupa brosur dan video singkat yang berisikan peraturan pengunjung, 4) Informasi Peraturan Pengunjung juga disebarkan sebelum wisatawan berkunjung dalam bentuk brosur dan video singkat mengenai Peraturan Pengunjung melalui tur operator, travel, hotel-hotel di sekitar Borobudur dan Jogjakarta, TIC, website, media sosial maupun Youtube, 5) Penyediaan spotspot menarik untuk berfoto di luar struktur candi dengan Candi Borobudur sebagai latar foto dan menyediakan stand untuk berfoto sebagai survenir untuk kemudian disosialisasikan melalui video, papan display, peta, brosur, website, media sosial, guide, fotografer dan petugas keamanan, 6) Mengatur alur kunjungan wisatawan di Zona 1 dalam upaya untuk mendistribusikan pengunjung secara seimbang di struktur Candi Borobudur dan di halaman candi dengan menyediakan pedestrian di halaman candi, signage serta menyediakan peta rute alur kunjungan dengan menekankan pada spot-spot penting atau menarik termasuk spot berfoto baik berupa papan display ataupun brosur, 7) Menyediakan tempat menunggu bagi wisatawan yang tidak naik ke struktur Candi Borobudur baik berupa ruang tunggu maupun tempat duduk di halaman candi bagi wisatawan yang tidak naik ke Candi Borobudur, 8) Memberitahukan kepada wisatawan tentang keberadaan video camera di struktur candi sehingga wisatawan akan mengetahui jika segala tindakannya di struktur candi terekam bahkan dilihat oleh wisatawan lain yang sedang menunggu di ruang tunggu.

\section{Daftar Pustaka}

Agustiani, H., 2006. Psikologi Perkembangan: Pendekatan Ekologi Kaitannya dengan Konsep Diri dan Penyesuaian Diri pada Remaja. Bandung: PT.Refika Aditama.

Arias, A., 2015. “Understanding and Managing Compliance in the Nature Conservation Context". Journal of Environmental Management. Vol 
$153: 134-143$

Azwar, S., 2013. Sikap Manusia Teori dan Pengukurannya. Yogyakarta : Pustaka Pelajar.

Cole, S., 2007. "Implementing and Evaluating a Code of Conduct for Visitors". Journal Tourism Management. Vol. 28 : 443-451

Gramann, J.H, Bonifield, R.L., 1995. "Effect of Personality and Situational Factors on Intentions to Obey Rules in Outdoor Recreation Areas". Journal of Leisure Research. Vol. 27 (4) : 326-343

Gramann, J.H.,Vander Stoep, G.A.. 1987. "Prosocial Behaviour Theory and Natural Resource Protection : a Conceptual Synthesis". Journal of Environmental Management. Vol. 4 (3) : 247-257

Harahap, Z., 2016. Faktor-Faktor yang Berhubungan dengan Ketidakpatuhan Terapi Arv pada ODHA Dewasa di Klinik VCT Kabupaten Cilacap. Tesis. Universitas Gajah Mada..

Hayes, D.G., 2008. An Investigation of Visitor Behaviour in Recreation and Tourism Settings: A Case Study of Natural Hazard Management at The Glaciers, Westland National Park, New Zealand. Disertasi. Lincoln University.

Mason, P. Mowforh, M., 1995. Code of Conduct in Tourism. University Of Plymouth

Notoatmojo, S. 2012. Promosi Kesehatan Dan Perilaku Kesehatan. Jakarta : PT.Rineka Cipta

Perdana, A., 2009. Pengaruh Sikap Menyederhanakan Gaya Hidup Secara Sukarela dan Sikap terhadap Peraturan Lingkungan pada Perilaku Bertanggungjawab pada Lingkungan. Tesis. Universitas Gajah Mada.

Rahardjo, S., 2010. Sosiologi Hukum : Perkembangan Metode dan Pilihan Masalah. Yogyakarta : Genta Publishing.

Rakhmat, J., 2003. Psikologi Komunikasi. Bandung: PT. Remaja Rosdakarya

Ratnadewi, E., 2005. Pengelolaan Tinggalan Budaya Melalui Pendekatan Visitor Management. Tesis. Universitas Gajah Mada.

Sarwono, S.W., 1992. Psikologi Lingkungan. Jakarta : Grasindo

Simmons, B.A., 1998. "Compliance With International Agreements". Annual Review Politic Science. 1998. Vol. 1:75.93

Smith, R.G., Anderson, K., 2004. Understanding Non-Compliance In The Marine Environment. Journal Trend \& Issues In Crime And Criminal Justice. No. 275

Soekanto, S., 2003. Sosiologi Suatu Pengantar. Jakarta : PT. Raja Grafindo Persada. 
Sulesuryana, R.S., 2007. Faktor yang mempengaruhi Perilaku Pengemudi Melanggar di Perlintasan Sebidang Kereta dan Kontribusinya terhadap Kecelakaan. Tesis. Universitas Gajah Mada.

Sutopo, dkk. 2013. Kearsitekturan Candi Borobudur. Magelang : Balai Koservasi Borobudur.

Taufik, M., 2005. Minimalisasi Dampak Negatif Pemanfaatan Candi Borobudur Sebagai Objek Wisata. Tesis. Universitas Gajah Mada.

Timothy, D.J, Boyd, S.W., 2003. Heritage Tourism. England : Pearson Educated Limited.

Undang-Undang Republik Indonesia Nomor 11 Tahun 2010 Tentang Cagar Budaya

Ward, C., Roggenbuck, J., 2003. “Understanding park visitors' response to interventions to reduce petrified wood theft". Journal of Interpretation Research. Vol. 8(1) : 67-82.

Winter, S.C., May. P.J. 2001. "Motivation for Compliance with Environmental Regulations". Journal of Policy and Analysis Management. Vol. 20(4) : 675-698

Yankholmes, A.K.B., Akyeampong, O.A., 2010. "Tourist Perceptions of Heritage Tourism Development in Danish-Osu, Ghana". International Journal of Tourism Research. Vol. 12 : 603-616

\section{Profil Penulis}

Aan Wahyuni Lestari, menyelesaikan jenjang S1 di Institut Teknologi Nasional Malang Tahun 2006, dan S2 di Arsitektur Pariwisata Universitas Gadjah Mada tahun 2017. Email: aan. wahyuni.l@gmail.com

Diananta Pramitasari, saat ini bekerja sebagai dosen di Program Studi Arsitektur Universitas Gadjah Mada. Jabatan saat ini sebagai Sekretaris Program Studi S3 Ilmu Arsitektur Universitas Gadjah Mada. Email : dpramitasari@ugm.ac.id

Ahmad Saifullah MJ, telah menyelesaikan tugas sebagai dosen di Program Studi Arsitektur Universitas Gadjah Mada pada tahun 2017. Email: saiful_tgp@yahoo.co.id 